\title{
Hepatitis B Infection and Liver Transplantation: The Art of the Possible
}

\author{
If a lot of cures are suggested for a disease, it means that the disease is incurable.
}

Anton Chekhov

Liver transplantation seems to be a lightning rod for many of the criticisms directed against high-technology tertiary care medicine. After the National Institutes of Health consensus conference declared in 1983 that "liver transplantation is a therapeutic modality for end-stage liver disease that deserves broader application" (1), there followed a period of remarkable growth. The number of liver transplants performed in the United States increased from 15 in 1985 to 2,656 by 1990 , and the number of liver transplant centers grew during the same period from 1 to 85 (2). The spirit of optimism that fostered this expansion has given way to a spirit of retrenchment, spurred in part by the general reassessment of public-health policy in the United States. Liver transplantation is very expensive and very labor-intensive and benefits relatively few patients. Many of these criticisms could be rebutted by convincing evidence that liver transplantation is an efficacious remedy for otherwise untreatable disease. Unfortunately, liver transplantation does not lend itself to randomized clinical studies of its efficacy. Physicians involved in liver transplant programs usually lack "equipoise" with regard to liver transplantation for their patients (3). In other words, because liver transplant physicians and surgeons are convinced that liver transplantation is the appropriate treatment for selected patients, they cannot in good conscience randomly allocate some of the same patients to a nontransplant arm of a clinical study. Nonetheless, it is incontrovertible that liver transplantation has been a lifesaving procedure for many patients who otherwise would have died. For example, among a cohort of alcoholic patients with end-stage liver disease who underwent transplantation evaluation, survival in the transplant recipients was significantly greater than that among patients not selected for transplantation (4). Indeed, it is this

HEPATOLOGY 1994;19:245-247

Address reprint requests to: Michael R. Lucey, M.D., F.R.C.P.I., Associate Professor of Medicine, Medical Director, Liver Transplant Program, University of Michigan Medical Center, 3912 Taubman Center, Box 0362, 1500 East Medical Center Drive, Ann Arbor, MI 48109.

Copyright (C) 1994 by the American Association for the Study of Liver Diseases.

$0270-9139 / 94 \$ 1.00+.10 \quad 31 / 1 / 51426$ perception of success that has fed the demand for liver transplantation.

A major limitation of the more widespread provision of liver transplantation is the lack of suitable donor organs. The demand for transplant livers has grown to outstrip the supply. As a result, the number of patients waiting for a liver transplant and the mean number of days each candidate waits continue to increase; inevitably the number of patients dying for want of a liver transplant has grown also (5). This crisis is forcing reconsideration of the goals of liver transplantation. Each time a donor liver is allocated to one particular recipient, other potential recipients are denied use of the same allograft. Many factors, including the patient's underlying diagnosis and severity of clinical decompensation, as indicated by the presence of kidney failure or the need for intensive care management before transplant, interact to affect the prognosis for successful engraftment and recovery (6). Given that we are able to allocate scarce donor organs to a few patients with end-stage liver disease only, what influence should the likelihood of a successful outcome have on the judgment of a potential candidate's suitability for transplant? The present United Network of Organ Sharing system is constructed to give priority to patients with the most immediate risk of dying. Approximately half of all recipients were stable (status 1 and 2) and half were more urgently ill (status 3 and 4) at time of transplant in 1992 (7). The philosophic basis of the system is to treat the most severely ill patients first, even though these patients are at greatest risk of postoperative mortality.

Chronic HBV infection presents a different aspect of the same dilemma. HBV-infected patients with endstage liver disease are often good surgical risks. Unfortunately, posttransplant infection of the allograft by HBV is very common, and the reported overall survival of HBV-infected patients who undergo transplantation is reduced. For example, Starzl et al. reported that the 24-mo survival after liver transplantation was $50 \%$ in 51 adults with HBV infection, compared with $76 \%$ in 744 adults given transplants for nonmalignant disease (8). Recurrent HBV infection in the allograft may be associated with an aggressive syndrome with the production of massive amounts of HBV proteins, which has been termed "fibrosing cholestatic hepatitis" (9). None- 
theless, the picture is not always gloomy. Some HBVinfected recipients, particularly patients coinfected with HDV, may tolerate HBV without obvious harmful effects and survive for many years after transplantation (10).

Because liver transplantation rarely cures chronic $\mathrm{HBV}$ infection, it has been questioned whether patients with chronic HBV infection should be considered appropriate liver transplant candidates. It is against this background that Marcellin's study in this issue of HEPATOLOGY provides important data (11). They studied the use of interferon- $\alpha$ (IFN- $\alpha$ ) in a group of patients with chronic hepatitis B infection and end-stage liver disease awaiting liver transplantation. The rationale for their study was sound. Previous studies had suggested that the risk for graft infection appeared to be greatest in patients with actively replicating HBV (12). Treatment of HBV infection with IFN- $\alpha$ can convert serum markers of viral replication ( $\mathrm{HBeAg}, \mathrm{HBV}$ DNA) to markers of less or no replication (HBe antibody [anti-HBe], absence of HBV DNA on standard hybridization techniques). This occurs in $40 \%$ to $50 \%$ of cases, whereas clearance of $\mathrm{HBsAg}$ occurs in a smaller percentage (13). Therefore, Marcellin et al. attempted to reduce the risk of infection of the graft by controlling HBV infection with administration of IFN- $\alpha$ in the pretransplant phase. Although they did not achieve all their goals, their results are important. Two of 22 patients had clinical serological and biochemical improvement, including loss of serum HBV DNA, allowing them to be taken off the waiting list. On the other hand, one patient deteriorated while on interferon, and spontaneous bacterial peritonitis developed. This patient subsequently improved with loss of HBV DNA from serum, appearance of anti-HBe and normal serum aminotransferase levels and was alive after $40 \mathrm{mo}$ without a transplant. IFN therapy in such a decompensated group of patients is hazardous, and eight of 22 patients required dosage reduction.

Eighteen IFN-treated patients underwent transplantation, and their results were compared with those in 26 historical controls. All patients received long-term immunoprophylaxis after transplantation. Previous studies by this group suggest that passive immunization with high doses of hyperimmune B Ig (HBIg) reduces the frequency of infection of the allograft with HBV (14). Marcellin and coworkers found that although IFN appeared to affect the viral load, it was ineffective in completely eradicating the virus before transplantation, and infection rates in the allograft were similar in IFN-treated and untreated patients (11). The antiviral effect was demonstrated by the disappearance of HBV DNA measured with dot-blot hybridization in seven of eight patients. However, in four of five patients who became HBV DNA negative during IFN therapy before transplantation HBV infection subsequently developed in their allografts. This observation was accounted for by means of analysis of stored pretransplant sera which indicated that persistence of the HBV genome, detected on PCR amplification rather than by means of standard hybridization methods, was highly associated with infection of the allograft. Thus it would appear that nothing short of complete eradication of the virus will protect against allograft infection.

What lessons are to be drawn from these studies, particularly in the light of the constraints on liver transplantation described earlier? First, we must define the goals of therapy. Until better therapies become available, curing the patient of HBV before transplantation by means of IFN is an unattainable goal $(11,15)$. Marcellin's observation that 2 of 22 patients improved sufficiently to forestall liver transplantation is interesting and worthy of further study. Hoofnagle et al. noted similarly that IFN treatment of patients with cirrhosis due to HBV infection, while carrying the risk of precipitating further deterioration, was associated with dramatic clinical improvement in some cases (16). It is appropriate to treat selected HBV-infected patients to this end alone. We need more studies to identify those patients most likely to respond in this way. It should be noted that pretransplant IFN should be administered in low doses and that a substantial portion of patients may require dose reduction. Second, this French group pioneered the use of posttransplant immunoprophylaxis with long-term high-dose parenteral $\mathrm{HBIg}$, and its role must be studied further. Even in France, as Marcellin's study shows, HBIg does not prevent recurrence of HBV in the graft. The PCR data presented here suggest that viremia at the time of transplant is the most important factor in determining posttransplant infection of the allograft. Marcellin's study included HBsAg-positive, anti-HBe-positive, HBV DNA-negative patients. The risk that these patients would infect the allograft is presumably less than that in patients with a high degree of viral replication. The role of HBIg should ideally be tested in a prospective randomized trial that takes the HBV replicative status of the participants into account. This has not been possible in the United States because of difficulty in procuring a supply of $\mathrm{HBIg}$, especially because the Food and Drug Administration has not approved an HBIg formulation suitable for intravenous use. Third, Marcellin's study shows that it is possible to manipulate HBV infection in patients awaiting liver transplantation, even if the ultimate goal of curing HBV has proved elusive. Research should be directed at examining the reasons why IFN is not more successful in eradicating HBV and identifying the factors that determine whether an allograft will become infected by HBV. These might include persistence of virus in extrahepatic sites (17), viral genetic mutation (18) or viral characteristics that reduce the efficacy of IFN (19). Similarly, study of more effective therapeutic agents, combinations of agents or use of baboon xenografts (20) should continue.

Finally, in my view, liver transplantation for patients with HBV infection should not be abandoned simply because it is not curative, although some acknowledgment of the donor shortage is appropriate. At the University of Michigan, we have adopted a policy of offering transplantation only to $\mathrm{HBV}$-infected patients 
who are suitable candidates in all other respects. We will not perform a second transplant if the primary allograft fails because of recurrent $\mathrm{HBV}$ infection. A similar policy of one donor organ per $\mathrm{HBV}$-infected candidate has also been followed in Toronto, albeit with the further restriction that only patients who test negative for $\mathrm{HBV}$ DNA in serum by means of standard hybridization methods will be considered for transplantation (Levy G, Personal communication, 1993). Until a consensus about the place of liver transplantation in management of HBV infection has been reached, it is reasonable to continue to include liver transplantation in the battery of therapies that may be directed against the difficult problem of end-stage liver disease due to HBV.

\section{MiCHAEL R. LUCEY, M.D., F.R.C.P.I. \\ Associate Professor of Medicine \\ Medical Director, Liver Transplant Program University of Michigan Medical Center Ann Arbor, Michigan 48109}

\section{REFERENCES}

1. National Institutes of Health Consensus Conference: Liver transplantation June 20-23, 1983. HePATOLOGY 1984;4(suppl):107S$110 \mathrm{~S}$.

2. Evans RW. The national cooperative transplantation study, Final Report. Bailette, Seattle 1991.

3. Freedman B. Equipoise and the ethics of clinical research. N Engl J Med 1987;317:141-145.

4. Lucey MR, Merion RM, Henley KS, Campbell Jr DA, Turcotte JG, Nostrant TT, Blow F, et al. Selection for and outcome of liver transplantation in alcoholic liver disease. Gastroenterology 1992 102:1736-1741

5. UNOS Update 1993;1:29-30.

6. Baliga $P$, Merion RM, Turcotte JG. Ham JM, Henley KS, Lucey MR, Schorck A, et al. Preoperative risk factor assessment in liver transplantation. Surgery 1992;112:704-711.

7. Turcotte JG. Donor organ retrieval, allocation, and logistics. In: Neuberger JM, Lucey MR. Liver transplantation: practice and management. London: BMJ Publications, in press.
8. Starzl TE, Demetris AJ, Van Thiel D. Liver transplantation. N Engl J Med 1989;321:1092-1099.

9. Davies SE, Portmann BC, O'Grady JG, Aldis PM, Chaggar K, Alexander GJM, Williams R. Hepatic histological findings after transplantation for chronic hepatitis B virus infection, including a unique pattern of fibrosing cholestatic hepatitis. HEPATOLOGY 1991;13:150-157.

10. Lucey MR, Graham DM, Martin P, Di Bisceglie A, Rosenthal S, Waggoner JG, Merion RM, et al. Recurrence of hepatitis B and delta hepatitis after orthotopic liver transplantation. Gut 1992; 33:1390-1396.

11. Marcellin P, Samuel S, Areias J, Loriot MA, Arulnaden JL, Gigou M, David MF, et al. Pretransplantation interferon treatment and recurrence of $\mathrm{HBV}$ infection after liver transplantation for hepatitis B related end stage liver disease. HEPATOLOGY 1994;19: 6-12.

12. Wright TL. The threat of hepatitis B virus recurrence: a sword of Damocles to the liver transplant recipient. HePatology 1993;18: 219-220.

13. Perrillo RP, Schiff ER, Davis GL, Bodenheimer Jr HC, Lindsay K Payne J, Dienstag JL, et al. A randomized, controlled trial of Interferon alpha-2b alone and after prednisone withdrawal for the treatment of chronic hepatitis B. N Engl J Med 1990;323:295-301.

14. Samuel D, Bismuth A, Mathieu D, Arulnaden JL, Reynes M, Benhamou JP, Brechot C, et al. Passive immunoprophylaxis after liver transplantation in HBsAg-positive patients. Lancet 1991; 337:813-815

15. Lavine JE, Lake JR, Ascher NL, Ferrell LD, Ganem D, Wright TL. Persistent hepatitis B virus following interferon alpha therapy and liver transplantation. Gastroenterology 1991;100:263-267.

16. Hoofnagle JH, Di Bisceglie AM, Waggoner JG, Park Y. Interferon alpha for patients with clinically apparent cirrhosis due to chronic hepatitis B. Gastroenterology 1993;104:1116-1121.

17. Yoffe B, Burns DK, Bhatt HS, Combes B. Extrahepatic hepatitis $B$ virus DNA sequences in patients with acute hepatitis $B$ infection. HEPATOLOGY 1990;12:187-192.

18. Carmen W. Thomas $H$, Domingo E. Viral genetic variation hepatitis B virus as a clinical example. Lancet 1993;341:349-353.

19. Foster GR, Goldin RD, Hay A, McGarvey MJ, Stark GR, Thomas HC. Expression of the terminal protein of hepatitis B virus is associated with failure to respond to interferon therapy. HEPATOLOGY $1993 ; 17: 757-762$

20. Starzl TE, Fung J, Tzakis A, Todo S, Demetris AJ, Marino IR Doyle $\mathrm{H}$, et al. Baboon-to-human liver transplantation. Lancet $1993 ; 341: 65-71$ 